\title{
Carolina Maria de Jesus e a autorrepresentação literária da exclusão social na América Latina: olhares reversos aos de Eduardo Galeano e Octavio Paz
}

Larissa Paula Tirloni ${ }^{1}$

Marcelo Marinho ${ }^{2}$

O processo de formação das nações latino-americanas resulta do violento confronto entre os conquistadores europeus, os subjugados povos indígenas e os massivos contingentes de escravos africanos forçados ao degredo em terra estrangeira. Nesse contexto, o confronto e a ocupação do território deram origem a múltiplos movimentos de diáspora, de exclusão social e de rejeição mútua entre grupos étnicos em busca de sobrevivência e de identidade: povos autóctones buscando refúgio em territórios não ocupados pelos conquistadores europeus, grupos de escravos africanos protegendo-se mutuamente em comunidades quilombolas, europeus deserdados e mestiços à caça de oportunidades em regiões inóspitas.

No âmbito da literatura, esse complexo embate entre dominadores e dominados, entre ricos e pobres, entre cidadãos e seres reificados, entre os que comem e os que têm fome, assim como o decorrente processo de exclusão social coercitiva, manifestam-se simbolicamente nas páginas dos mais significativos escritores latino-americanos, de José de Alencar a Gabriel García Marquez, de Augusto Roa Bastos a Miguel Ángel Asturias, entre inúmeros outros exemplos extremamente representativos. Coetâneos, o diplomata, poeta e ensaísta mexicano Octavio Paz (México, 1914-1998) e o jornalista, ensaísta e poeta Eduardo Hughes Galeano (Uruguai, 1940-) inscrevem-se entre os autores que, por intermédio de sua obra, constroem uma inovadora e expressiva imagem da América Latina, no tocante aos segmentos negligenciados da população. Nesse contexto, é fundamental registrar o surgimento de uma voz que emerge das próprias favelas para denunciar, como testemunho pessoal de fatos empíricos cotidianos, o fosso profundo que separa famintos e bem alimentados no conjunto do continente latino-americano: a memorialista e ficcionista brasileira

\footnotetext{
${ }^{1}$ Doutoranda em estudos literários e professora da Universidade Estadual do Oeste do Paraná (Unioeste), Foz do Iguaçu, PR, Brasil. E-mail: larissatirloni@hotmail.com

${ }^{2}$ Doutor em literatura comparada e professor da Universidade Federal da Integração LatinoAmericana (Unila), Foz do Iguaçu, PR, Brasil. E-mail: biografia@gmail.com
} 
Carolina Maria de Jesus (Brasil, 1915-1977). No conjunto da obra desses autores, observa-se o impacto da exclusão social no processo de construção das identidades nacionais. Nessa perspectiva, nas últimas décadas, a representação literária da exclusão social tornou-se um dos temas privilegiados dos estudos comparatistas, sobretudo pela vertente dos estudos culturais e da crítica social.

O presente trabalho centra-se no estudo comparativo da imagem literária da exclusão social, por intermédio da representação desse fenômeno, tal como se estampa nas páginas autorreferenciadas de Carolina de Jesus, que assume a (verdadeiramente autorizada) voz autoral de uma catadora de papel, mulher, negra, mãe, descendente de escravos no Brasil, chefe única de família, migrante sem opção, moradora em favela, ser humano privado de cidadania. Para tanto, toma-se como ponto de partida a visão externa do fenômeno da exclusão que se observa nas páginas de dois autores de ascendência europeia, de traços caucasianos, de extração e posição social privilegiada, entre outras marcas de pertencimento sociocultural: Octavio Paz e Eduardo Galeano. Tal leitura comparatista justifica-se pelo fato de a representação da exclusão social ser um fenômeno produtor e mediador de sentidos no conjunto da sociedade, sobretudo por meio da literatura e de outras manifestações artísticas. Para a condução de tal reflexão, este trabalho assim se estrutura: na primeira parte traça-se um breve panorama da representação da exclusão social na literatura; na segunda, apresentam-se elementos de reflexão sobre a exclusão social na obra de Octavio Paz, e, com base em conceitos propostos pelo prêmio Nobel mexicano, procede-se a uma leitura contrastiva da imagem da exclusão em um célebre poema do uruguaio Eduardo Galeano; na terceira parte, por fim, passa-se ao reverso da leitura contrastiva e à analise da expressiva voz autoral da brasileira Carolina Maria de Jesus, em suas páginas autorreferenciadas e suas imagens especulares que se constroem ao arrepio do olhar exterior e exotizante de Galeano e Paz.

\section{A representação da exclusão social na literatura brasileira}

O conjunto da literatura ficcional é marcado por autores e obras que plasmam histórias representativas de grupos sociais (por meio de personagens individuais ou coletivos): histórias relativas aos demais grupos são preteridas e silenciadas. Em tal contexto, a concepção e elaboração de novas narrativas poéticas adotam ou recusam modelos 
literários predeterminados, modelos canonizados por instituições como a crítica, as escolas, as universidades, as editoras, a imprensa, os organismos de fomento à produção literária. Quando, no âmbito da literatura, determinam-se modelos narrativos, isolam-se e calam-se os textos que destoam e recusam o cânone vigente no que se refere a temas, perspectivas sociais e formas estéticas. Toda escolha e seleção implica apagamento, silêncios e lacunas: o cânone representa os interesses de grupos sociais dominantes. Por vezes, escolhas poéticas particulares podem resultar em novas histórias e/ou novos moldes literários, podem se transformar em cânones ou conservar sua condição de marginais, conforme relembra Maria Eunice Moreira:

Oficiais ou marginais, restritos ou amplos, todos os cânones são seletivos e, como tal, elitistas. Todo cânone está em processo e em permanente atualização e falar em abertura do cânone é uma redundância, pois esse está aberto, tanto para as exclusões quanto para as inclusões (Moreira, 2003, p. 92).

Nas últimas décadas, o deslocamento centrífugo das margens do cânone e a ampliação de perspectivas nos estudos literários resultaram na inclusão de fatos históricos, formas estéticas e temas sociais até então negligenciados ou silenciados. Tomando-se a literatura ficcional como uma forma de interpretação e registro simbólico de fatos sociais, notase, no último quartel do século $X X$, a nítida ampliação do número de personagens e autores que representam grupos socialmente dominados, tais como segmentos urbanos e rurais que vivem abaixo da linha da pobreza, mulheres, homossexuais, indígenas e negros. Tal abertura também contempla e integra as formas da cultura popular, incluindo as manifestações de linguagem que se subtraem às normas cultas do discurso - outra eficaz ferramenta de dominação social. Essas obras expressivamente emergentes são social e literariamente relevantes não só por representarem, de forma ficcional, fatos relativos aos guetos socioeconômicos mas também por permitirem que certos autores logrem evadir-se dos guetos literários demarcados pelas instituições que criam e consolidam os cânones culturais e literários.

Esses autores periféricos são caracterizados pela expressão "literatura marginal", termo que se disseminou no cenário cultural contemporâneo como referência à produção de autores que assumem um lócus de enunciação periférico ou centrífugo (do ponto de vista social, editorial e jurídico) e estão trazendo para o campo literário temas 
e linguajar igualmente "marginais". Essa é a perspectiva analisada por Sérgius Gonzaga e retomada por Luana Teixeira Porto, quando afirma que a marginalidade em literatura é uma condição acessória:

a) à posição dos autores no mercado editorial, considerando a existência de escritores cujas obras são produzidas e distribuídas fora do sistema editorial vigente; b) ao tipo de linguagem apresentada nos textos, a qual apresentaria uma espécie de recusa da linguagem institucionalizada ou aos valores literários de uma época; c) à escolha dos protagonistas, cenários e situações presentes nas obras literárias, os quais atenderiam o desejo do escritor de reler o contexto de grupos oprimidos, buscando representá-los nos textos (Porto, 2012, p. 140-141).

Assim, ao se subtrair às sombras da indiferença e dos preconceitos, a chamada "literatura marginal" carreia à luz do dia atores sociais cujas histórias individuais integram e explicam aspectos intrínsecos da existência humana. Dessa forma, a literatura abre espaços para a manifestação de vozes até então silenciadas, contribuindo para ampliar a noção de identidade nacional. Nessa perspectiva, em seu abrangente estudo comparatista intitulado Formação da literatura brasileira, o sociólogo e crítico literário Antonio Candido analisa o processo de afirmação identitária cultural brasileira ao longo dos séculos XVIII e XIX, que se serviu, num primeiro momento, da imagem idealizada dos autóctones (ou povos originários), diluindo-se na simplicidade da imagem a multivalência da identidade do povo brasileiro. Tais condições de produção e consolidação de identidades estenderam-se, posteriormente, ao caipira, ao caboclo, ao sertanejo; e em seguida, a um movimento engajado e preocupado com questões sociais, com o objetivo de denunciar os problemas e mazelas da sociedade brasileira.

Antonio Candido analisa os textos produzidos no afã do Romantismo brasileiro e afirma que "a literatura foi considerada parcela dum esforço construtivo mais amplo, denotando o intuito de contribuir para a grandeza da nação" (1997, p. 11-12) por intermédio de uma literatura nacional que representasse, simbolicamente, segmentos expressivos da população do país, silenciando, contudo, sobre largas parcelas da população que, por meio de um intrincado jogo de espelhos, tornam-se segmentos inexpressivos do ponto de vista do imaginário nacional, retroalimentando tal processo de estruturação social. Conforme sustenta a historiadora Márcia Regina Naxara (1998, p. 108- 
109), a diversidade de culturas decorrente da chegada de centenas de milhares de imigrantes ao Brasil, contingente que se somou (mas também se subtraiu e se sonegou) aos indígenas, negros e portugueses, fez com que se acentuasse ainda mais a plurivalência cultural e o significado da exclusão social na construção da identidade corrediça do povo brasileiro. A pesquisadora assim analisa as relações entre preconceito, exclusão social e pertencimento étnico:

O preconceito básico em relação aos povos de pele morena - quanto mais branco, mais próximo da civilização; quanto mais moreno, mais dela afastado e incapacitado. Todas as outras diversidades podiam, de certa forma, estar contidas nesta, determinando as nuanças das abordagens, quer literárias, quer políticas (Naxara, 1998, p. 115).

No que tange à representação da exclusão social na literatura, vale notar que o negro é um elemento emblemático do ponto de vista do imaginário poético nacional, visto que, no mais das páginas, sua imagem é apresentada de forma grotesca e caricatural, como se observa, por exemplo, no célebre e canônico Monteiro Lobato, criador de uma Tia Nastácia que, em sua negritude, representa uma pretensa estreiteza e ingenuidade de imaginação e de cultura, que seriam próprias daqueles que se encontram socialmente excluídos e silenciados, em razão da cor da pele, da origem geográfica ou da renda abaixo da linha da pobreza, como se infere da análise proposta por Marisa Lajolo (1998). O próprio nome sincopado ("Nastácia" no lugar de "Anastácia") do famoso personagem indica sua incompletude, sua inaptidão até mesmo para a comunicação.

Vale sublinhar que a imagem veiculada pela personagem de Tia Nastácia se consolida no país por meio de adaptações televisivas, de história em quadrinhos (cujas edições atuais merecem uma análise crítica) ou mesmo em composições musicais (tal como ocorre em criação de Dorival Caymmi retomada pelo grupo Balacobaco ou por Zeca Pagodinho, em que se celebra e se enaltece a docilidade ancilar de Nastácia frente ao Sinhozinho). Pelo viés oposto, escritores como João Ubaldo Ribeiro, autor de Viva o povo brasileiro (1984), tendem a reverter esse painel por intermédio de uma narrativa mais próxima da cultura e da voz popular, oferecendo ao leitor, pertencente a outros estratos sociais, a oportunidade de se aproximar das camadas marginalizadas por meio da representação literária dessas vozes silenciadas no cânone literário.

Em tal contexto, muitos aspectos conteudísticos e também de cunho estilístico projetam o alcance dessas propostas de escrita literária: por 
exemplo, a estrutura fortemente paratática e elíptica que caracteriza o romance Cidade de Deus (1997), de Paulo Lins, traduz o empilhamento de pessoas-objeto na favela, como se parataxes, síncopes e elipses correspondessem à voz engasgada dos que se encontram à margem e representassem metaforicamente vidas fragmentadas e silenciadas, uma peculiar e sofrida condição de existência. Por esse prisma, observa-se que a assim chamada "literatura marginal" é de fundamental importância para a interpretação das condições de vida em nosso país, uma vez que propõe novas interpretações, pelo viés da ficção, para os fatos cotidianos de uma parcela da humanidade que traz em si a imagem especular do conjunto das experiências humanas. No que tange à virada estética e discursiva que se plasma na virada cronológica do século XXI, esta é a análise que propõe Terry Eagleton, o renomado e provocativo teórico da literatura:

Enquanto os críticos literários vinham cultivando a sensibilidade de uma minoria, grandes segmentos dos meios de comunicação de massa empenhavam-se em disseminá-la entre a maioria [...] Silenciados por gerações inteiras, aprendendo a considerar a literatura uma atividade de elite, fora de seu alcance, os operários da Grã-Bretanha vêm se organizando ativamente nos últimos dez anos para encontrar seus estilos e suas vozes próprias. O movimento dos escritores proletários é quase desconhecido dos meios acadêmicos, mas é um dos indícios de um rompimento significativo com as relações predominantes de produção literária (Eagleton, 1997, p. 296-297).

Em perspectiva convergente, o escritor e roteirista Ferréz arranca a voz da favela para fora dos muros do gueto literário, com seu romance Capão Pecado (2005a), em cujas páginas sublinha-se a violência cotidiana na vida dos favelados paulistanos, os excluídos no preciso coração convulso da economia nacional. Ferréz assim discorre sobre a literatura marginal, produto da "periferia/favela/gueto":

Quem inventou o barato não separou entre literatura boa/feita com caneta de ouro e literatura ruim/escrita com carvão, a regra é só uma, mostrar as caras. Não somos o retrato, pelo contrário, mudamos o foco e tiramos nós mesmos a nossa foto. [...] Jogando contra a massificação que domina e aliena cada vez mais os assim chamados por eles de "excluídos sociais" e para nos certificar de que o povo da periferia/favela/gueto tenha sua colocação na história, e que não fique mais quinhentos anos jogado no limbo cultural de um 
país que tem nojo de sua própria cultura, a literatura marginal se faz presente para representar a cultura de um povo, composto de minorias, mas em seu todo uma maioria (Ferréz, 2005b, s.p.).

A "literatura marginal", como se observa, assume o compromisso de se tornar um dos fatores humanizadores da sociedade e, paradoxalmente, do próprio ser humano. Seus personagens representam vivências ignoradas pela maioria do público leitor e participam da difusão de uma literatura extracanône que denuncia as mazelas do cotidiano de pessoas que se encontram às margens da sociedade, por vezes às margens da própria vida. No caso do Brasil, Carolina Maria de Jesus - mulher, favelada e negra - foi a primeira escritora a escapar do gueto literário e irromper no espaço editorial controlado pela burguesia dominante, com seu relato memorialista Quarto de despejo: diário de uma favelada (2006 [1960]). Em sua obra, Carolina imprime em letras capitais seu grito de denúncia contra a fome, a pobreza, a violência moral e física, a coerção social, o descaso, o preconceito, a marginalização, o silenciamento que oprimem os excluídos. De forma convergente, ampliando-se para o contexto latinoamericano, o ensaísta e ficcionista uruguaio Eduardo Galeano, autor do célebre Veias abertas da América Latina (1971), publica El libro de los abrazos (1989), uma coletânea de textos em prosa poética que inclui o poema "Los nadies" (Os ninguéns), dedicado aos mesmos excluídos retratados por Carolina. Esses autores representam literariamente o universo dos excluídos, uma tentativa de construir uma identidade nacional em que se inclua essa comunidade de esquecidos - os "ninguneados" de que trata o Octavio Paz, como analisaremos nas próximas páginas, por meio de uma perspectiva comparatista focada num dos mais célebres poemas de Galeano.

\section{Os “ninguneados” de Octavio Paz, os “nadies” de Galeano}

Octavio Paz: poeta, ensaísta, tradutor, diplomata e Prêmio Nobel mexicano. Nascido em 31 de março de 1914, na Cidade do México, e falecido em 19 de abril de 1998. O registro dessas datas é como o anúncio de um século de reviravoltas na história mundial. Nascendo sob o signo da Primeira Grande Guerra e às vésperas de convulsões como a Revolução Russa ou a Revolução Mexicana, a infância de Paz é marcada por indicadores de um tempo de profundas mudanças. 
Recebeu o Prêmio Nobel de Literatura no ano de 1990 por um conjunto de obras em que se destaca a reflexão social e política: El laberinto de la soledad (1997 [1950]), Posdata (1969), El ogro filantrópico (1978), Tiempo nublado (1983) e Pequeña crónica de grandes días (1990). Essa obra poética é variada e exerce larga influência na poesia contemporânea.

Na esteira de uma fenomenologia inspirada em Heidegger, o poema intitulado "Respuesta y reconciliación" (1998) termina com estes versos, nos quais o ser humano, em sua condição existencial, é comparado a uma árvore cujos frutos são as palavras, entidade incorpórea por cujo intermédio se materializam sentimentos e ideias: "Árbol de sangre, el hombre siente, piensa, florece/ y da frutos insólitos: palabras./ Se enlazan lo sentido y lo pensado,/ tocamos las ideas: son cuerpos y son números" (Paz, 1998, p. 9). No universo das palavras é que se realiza a existência humana, ensina o poema. Tal condição encontra-se igualmente na inspiradora intuição de Michel Foucault: o filósofo observa que Dom Quixote "lê o mundo para confirmar os livros" - a leitura das palavras precede a leitura do mundo, as palavras conformam nossa visão do mundo.

No contexto em que novas palavras representam novas maneiras de compreender o universo, "Ningunear" é um vocábulo cunhado por Paz, termo cuja fortuna amplia-se dia a dia nos países de língua hispânica. $\mathrm{Na}$ esteira dessa fortuna, a versão eletrônica do Dicionário da Real Academia Espanhola traz estes significados para o vocábulo: "1. tr. No hacer caso de alguien, no tomarlo en consideración. 2. tr. Menospreciar a alguien." Nos dias de hoje, em língua espanhola, o termo é amplamente utilizado, inclusive no âmbito da linguagem jurídica, pois representa uma das formas de assédio moral no ambiente de trabalho. A fortuna da invenção de Paz pode ser constatada pela espantosa soma de 1,5 milhões de ocorrências do termo, indicada pelo mecanismo de buscas do Google, assim como 170 mil ocorrências para "ninguneado", $210 \mathrm{mil}$ para "ninguneo", registradas em março de 2014.

A ação de "ningunear" transcende o ato de ignorar a presença de outra pessoa, mesmo que involuntariamente. O ato de "ningunear" implica um significativo e voluntário menosprezo, decorre do desejo implícito ou manifesto de fazer com que o outro apague sua existência e introjete o próprio apagamento - apague-se para si mesmo. "Ningunear", verbo transitivo: para além de qualquer ocorrência de aspecto acidental ou fortuito, a ação que decorre do desprezo por outrem implica uma percepção prévia desse Outro. Tal atitude equivale 
à manifestação explícita da indiferença - agir como se o outro não existisse. Nesse quesito, as ideias de Octavio Paz demonstram em que medida todas as sociedades se assemelham à mexicana:

No sólo [los mexicanos] nos disimulamos a nosotros mismos y nos hacemos transparentes y fantasmales; también disimulamos la existencia de nuestros semejantes. No quiero decir que los ignoremos o los hagamos menos, actos deliberados y soberbios, los disimulamos de manera más definitiva y radical: los ninguneamos. El ninguneo es una operación que consiste en hacer de Alguien, Ninguno. La nada de pronto se individualiza, se hace cuerpo y ojos, se hace Ninguno (Paz, 1997, p. 48-49).

A coletânea de ensaios intitulada El laberinto de la soledad (1997 [1950]) discorre sobre aspectos constituintes da identidade mexicana, corrediça e em permanente transformação: o próprio título já indica a complexidade inextricável das trilhas que se entrecruzam e formam o tecido imaginário da alma desse povo assentado no espaço corrediço do entrelugar: entre Norte e Sul, Atlântico e Pacífico, povos originários e conquistadores espanhóis, dominadores e dominados, modernidade e tradição, catolicismo e paganismo. Em tal perspectiva, o ensaísta observa que a solidão, nesse contexto, termina por se tornar um sentimento difuso na cultura mexicana. Assim, a metáfora do labirinto corresponde à multiplicidade de peculiaridades e idiossincrasias que caracteriza os traços distintivos da formação sociocultural mexicana. Por extensão, pode-se ampliar o alcance das ideias de Octavio Paz ao conjunto da América Latina, cuja identidade encontra-se em permanente mobilidade corrediça, sobretudo em função da megadiversidade cultural que caracteriza o subcontinente. Nesse sentido, vale notar que os múltiplos intérpretes das fecundas ideias de Octavio Paz servem-se desses conceitos para analisar os aspectos constitutivos da identidade de inúmeros outros povos e nações. Por esse viés, Karla Cunha deduz que o ser humano, tal como o mexicano analisado por Paz, situa-se precisamente no labirinto do entrelugar, no espaço vazio da solidão, volta-se sobre si mesmo perdido no fluxo contínuo de sua constante contradição, uma vez que se autoafirma e se autorrecusa de forma simultânea:

As trilhas do labirinto são inúmeras e a história se move a partir dessas incertezas. O moderno nos aponta para o futuro, procura desviar nosso olhar das imagens pretéritas, desfazer nossas 
lembranças, ora substituindo-as por utopias, ora pela busca constante do novo. Elas evidenciam que algo foi perdido, talvez a harmonia entre o homem e a natureza ou a identidade entre a palavra e a coisa. Há um mal-estar permanente que atravessa a construção da cultura. Tudo isso se relaciona com a condição humana, marcada pela imperfeição e pela mortalidade. A nossa capacidade de inventar e criar não nos livra nem da solidão, nem do labirinto (Cunha, 2004, p. 7).

No que tange às múltiplas possibilidades de manifestação do menosprezo característico do "ninguneo", essa forma violenta de relacionar-se com o Outro assume diversas formas: silêncios, palavras, gestos físicos ou simbólicos. O indivíduo ou grupo de pessoas que sofre "ninguneo" sente-se diminuído frente aos demais indivíduos ou grupos: a violência psicológica é discreta e lancinante, desencadeia e instala um doloroso processo interno de autonegação e apagamento. Do ponto de vista social, o "ninguneo" é uma forma de profunda segregação em que parcela da população torna-se transparente aos olhos da nação, pelo fato de ser apagada de toda e qualquer forma de discurso, do jornalístico ao jurídico, do pedagógico ao historiográfico, do folclórico ao artístico, do fotográfico ao literário, do privado ao público, do particular ao oficial. Esses segmentos da população têm sua existência insistentemente negada, e tal fato ocorre por intermédio do discurso: são os "ninguneados" da nação, são os "João Gostoso" de que fala Manuel Bandeira, moradores de "barracões sem número", pessoas sem nome, sem endereço, sem identidade, sem existência individual ou cidadã, dissolvidas numa coletividade amorfa e anônima - "zéninguém", "don nadie", "ningun". Ora bem, tal "ninguneo" manifestase de forma emblemática no conjunto da produção literária do país, sobretudo em razão das insustentáveis condições econômicas em que vivem esses segmentos (indígenas, negros, analfabetos, portadores de necessidades especiais, grupos abaixo da linha de pobreza absoluta etc.). Por esse viés, em sua denúncia acerca de todas as formas de exclusão, Octavio Paz assegura que

la caída de la Unión Soviética nos ha hecho ver ahora con mayor claridad los vicios y defectos de las democracias liberales capitalistas. La crítica al sistema que nos rige ha recobrado toda su vigencia y actualidad. El mercado es el motor que mantiene a 
la economía pero asimismo es la aplanadora que aplasta pueblos y naciones enteras (Paz, 1996, p. 12).

Ao desentranhar dos meandros invisíveis da cultura e ao nomear uma característica comportamental própria aos confrontos simbólicos também no âmbito das modernas sociedades latino-americanas, Paz demonstra sua condição de pensador profundamente comprometido com seu tempo histórico. O século XX deve a Octavio Paz a elaboração de um abrangente panorama analítico que contribui para a compreensão das formas de funcionamento do mecanismo de exclusão nas Américas ou, talvez com mais propriedade, no conjunto de todas as sociedades ou grupos humanos. Numa perspectiva eminentemente comparatista e latino-americanista, cabe analisar os pontos de confluência entre as ideias de Paz e o processo de representação literária da exclusão social em Eduardo Hughes Galeano. Na esteira aberta pelo diplomata mexicano, Galeano ecoa poeticamente o conceito de "ninguneo" no tema de seu poema narrativo intitulado "Los nadies", cujos versos põem em cena os sujeitos historicamente excluídos da sociedade e apagados de todas as formas de discurso, tal como se vê nesta transcrição do célebre poema:

\section{Los nadies}

Sueñan las pulgas con comprarse un perro y sueñan los nadies con salir de pobres, que algún mágico día llueva de pronto la buena suerte, que llueva a cántaros la buena suerte; pero la buena suerte no llueve ayer, ni hoy, ni mañana, ni nunca, ni en lloviznita cae del cielo la buena suerte, por mucho que los nadies la llamen y aunque les pique la mano izquierda, o se levanten con el pié derecho, o empiecen el año cambiando de escoba.

Los nadies: los hijos de los nadies, los dueños de nada.

Los nadies: los ningunos, los ninguneados, corriendo la liebre, muriendo la vida, jodidos, rejodidos:

Que no son, aunque sean.

Que no hablan idiomas, sino dialectos.

Que no profesan religiones, sino supersticiones.

Que no hacen arte, sino artesanía.

Que no practican cultura, sino folklore.

Que no son seres humanos, sino recursos humanos.

Que no tienen cara, sino brazos.

Que no tienen nombre, sino número. 
Que no figuran en la historia universal, sino en la crónica roja de la prensa local.

Los nadies, que cuestan menos que la bala que los mata. (Galeano, 1989, p. 52)

A imagem inaugural do poema sintetiza a condição existencial dos socialmente excluídos: "Sueñan las pulgas con comprarse un perro y sueñan los nadies con salir de pobres" (Galeano, 1989, p. 52). O texto, de forma irônica e sarcástica com relação aos discursos compartilhados pelas classes dominantes e introjetados pelos segmentos dominados, explora a difundida analogia entre "pobre" e "pulga": o animal e o ser humano assemelham-se por manifestarem desejos simultaneamente comezinhos e inalcançáveis, por demonstrarem equivalente poder de sonho e pensamento - poder nulo, sonhos vãos, imaginação chã! A pulga e o pobre não têm voz nem vez, em sua condição de seres invisíveis e sem significância que "infestam" e perturbam a existência dos demais, forçados a sobreviver com os restos do sangue simbólico sorrateiramente retirado do tecido alheio - no caso do pobre, o tecido social alheio, ao qual não pertence, do qual está excluído. Nesse poema, o empilhamento de vozes palimpsésticas alcança um forte valor expressivo: Galeano reformula poeticamente certos chavões que circulam em sua classe social, cuja insistente repetição termina por se introjetar até mesmo na forma com que os excluídos se percebem e se pensam. Cabe notar que o poema se constrói com o uso da terceira pessoa: o narrador fala ao narratário sobre uma terceira entidade, tema ou objeto do discurso enunciado. Em outras palavras, é um discurso sobre os socialmente excluídos que exclui, no âmbito do próprio discurso, aqueles que já estão excluídos. É um discurso dos que comem para os que também saciam sua fome. Tais imagens, claro está, correspondem a uma visão exterior do universo dos excluídos: é a voz dos bem alimentados descrevendo a vida dos famintos. Com base nessas ideias, lançaremos um olhar contrastivo sobre as páginas da catadora de papel que se transformou em autora essencial da literatura latino-americana.

\section{Carolina de Jesus: o silêncio dos que comem, a voz dos que têm fome}

Com esteio nos conceitos e leituras até agora apresentados, passamos a analisar comparativamente as formas de representação literária da 
exclusão social, agora nas páginas autorreferenciadas da memorialista brasileira Carolina Maria de Jesus, em confronto com o discurso engajado de Galeano e Paz. Por intermédio de seu diário Quarto de despejo: diário de uma favelada (2006), Carolina assume uma voz autoral de grande expressividade poética e apresenta aos leitores o universo existencial em que se vive a exclusão social e cultural, na vida e atribulações cotidianas de uma moradora de favela. Carolina Maria de Jesus nasceu no ano de 1914, na cidade de Sacramento, fundada em 1820 no sertão profundo de Minas Gerais. Na idade adulta, desnorteada pela falta de perspectivas como milhões de outros brasileiros -, migrou para a cidade de São Paulo, atraída, como uma lucíola, pela chama do candeeiro. Descendente de escravos, traz consigo os hereditários estigmas do tempo: mulher, pobre, negra, migrante, sem acesso à educação formal. Seu livro resulta de anotações esparsas feitas em folhas reaproveitadas de seu ofício cotidiano: catadora de papel nas ruas e aterros sanitários da capital, que então se industrializava. Suas anotações sobre sua própria vida de excluída foram descobertas pelo jornalista Audálio Dantas, que passou a publicá-las em jornais a partir de 1958. Dois anos mais tarde, a livraria Francisco Alves lança Quarto de despejo: diário de uma favelada, organizado por Dantas. O livro atingiu a impressionante marca dos 10 mil exemplares vendidos na primeira semana, 100 mil no espaço de um ano. O diário de Carolina foi logo traduzido para idiomas como inglês, francês, espanhol, alemão, japonês (Lajolo, 2011, p. 439-440).

No título Quarto de despejo, observa-se o olhar centrífugo, de dentro para fora, que obedece à força endógena de uma autora que busca escapar do espaço restrito e restritivo que a história da formação da América Latina reservou para ela e seus descendentes: um olhar que vem dos fundos da peça da moradia familiar que se reserva aos serviçais domésticos e aos objetos sem serventia - o moderno avatar da senzala em que se confinavam os escravos. Por outro lado, o termo "despejo" já aponta para as vidas invisíveis que se mantêm com restos alheios e sobras sem serventia que são o pão cotidiano dos excluídos, árdua e sorrateiramente obtido, tal como o sangue que alimenta as pulgas - "muriendo la vida", ecoa Galeano, essa é a condição dos que se se alojam, morrendo suas vidas, no entrelugar cataléptico ("vidas secas", para Graciliano Ramos) dos despejos, favelas, aterros sanitários. Com seu conhecimento de causa, Carolina Maria de Jesus perscruta para muito além das ideias de Galeano e ressalta até mesmo as possíveis 
vantagens dos animais com relação à vida dos favelados: “Talvez entre elas [aves] reina amizade e igualdade. [...] $\mathrm{O}$ mundo das aves deve ser melhor do que dos favelados, que deitam e não dormem porque deitam-se sem comer" (Jesus, 2006, p. 30).

Em voz própria, denunciando aos leitores o lado mais cruel da vida dos favelados-ninguneados, a autora evidencia a desconstrução, a reificação e a animalização desses excluídos que, por necessidade de sobrevivência, precisam disputar alimento com os corvos: "Os favelados aos poucos estão convencendo-se que para viver precisam imitar os corvos" (Jesus, 2006, p. 37). Seu alimento é disputado nos despejos dos aterros sanitários, no meio dos restos e sobras que já não servem a humano algum, servem apenas a "Los nadies: los hijos de los nadies, los dueños de nada", como se vê na reverberação externa lançada por Galeano em eco ao grito endógeno de denúncia de Carolina. “Donos de nada", nem mesmo de condições minimamente humanas de sobrevivência: imitar pulgas e corvos é o que lhes compete na partilha desigual do mundo. A representação desse aspecto da exclusão social é patente em Quarto de despejo, no episódio em que uma mãe, para evitar a morte por inanição juntamente com seus três filhos, vê-se obrigada a buscar nos aterros sanitários - os lixões - restos e despejos de resíduos imprescindíveis à sua subsistência. Esses são "Los nadies: los ningunos, los ninguneados, corriendo la liebre, muriendo la vida, jodidos, rejodidos", aqueles que passam fome ("correr la lebre"), pessoas à margem da sociedade, à margem da vida e de si próprios, que perdem suas vidas no consumo das sobras de vida que lhes cabem nos despejos desse latifúndio:

Os lixeiros haviam jogado carne no lixo. E ele escolhia uns pedaços: Disse-me: - Leva, Carolina. Dá pra comer. Deu-me uns pedaços. Para não magoá-lo aceitei. Procurei convencê-lo a não comer aquela carne [...]. Ele disse-me que não. Que há dois dias não comia [...]. No outro dia encontraram o pretinho morto (Jesus, 2006, p. 35-36).

Por sua visão simultaneamente endógena e centrífuga, os relatos autobiográficos de Carolina representam literariamente a vida cotidiana dos excluídos e contribuem para o conhecimento e a compreensão da condição de "ninguneados" nas relações sociais, segmento social ausente dos discursos canônicos que constroem a identidade da nação. Em meio aos dejetos urbanos no grande "quarto de despejo" que são os aterros sanitários e favelas, a "vida que se morre" resulta da reificação de seres humanos que se confundem com corvos, ingurgitam podridão 
letal e respiram o odor fétido da humilhação, do descaso, da exclusão social e do esquecimento. $\mathrm{O}$ "ninguneo" reflete-se em degradação do indivíduo e do grupo de excluídos, instalados em um espaço (físico e simbólico) em que se despejam instrumentos de trabalho: Galeano sublinha, com o olhar conhecedor dos segmentos hegemônicos que procedem à divisão do trabalho, "que no son seres humanos, sino recursos humanos". Tais "recursos humanos", ao perderem sua serventia, tornam-se o próprio "despejo" que se incinera ou se descarta indistintamente, como diz, em discurso de autoconhecimento, Carolina:

As oito e meia da noite eu já estava na favela respirando o odor dos excrementos que mescla com o barro podre. Quando estou na cidade tenho a impressão que estou na sala de visita com seus lustres de cristais, seus tapetes de viludos, almofadas de sitim. E quando estou na favela tenho a impressão que sou um objeto fora de uso, digno de estar num quarto de despejo. [...] Estou no quarto de despejo, e o que está no quarto de despejo ou queimase ou joga-se no lixo (Jesus, 2006, p. 33).

Carolina Maria de Jesus concebe e elabora uma inédita imagem literária de seu próprio segmento social, denuncia as mazelas de um povo sofrido, silenciado e esquecido, formado por pessoas "Que no son, aunque sean", seres reificados "que no tienen nombre, sino número", equivalentes a "objetos que estavam na sala de visita e foram para o quarto de despejo". (Jesus, 2006, p. 34). Nesse irrepresável discurso de fatura endógena e centrífuga, muito próximo à combustão espontânea e ao fogo fátuo, a impossibilidade de existência cidadã é denunciada mesmo para além da morte anônima, como descreve Carolina: "No outro dia encontraram o pretinho morto [...] Não trazia documentos. Foi sepultado como um Zé qualquer. Ninguem procurou saber seu nome. Marginal não tem nome" (Jesus, 2006, p. 36). Uma vida em silêncio dá lugar a uma existência esquecida, o nada dá lugar a menos que nada: coletividade amorfa e anônima - "Zé Ninguém", "Don Nadie", "Ningun", "João Gostoso".

A estrutura fragmentada do diário de Carolina, marcada por frases curtas e paratáticas, por síncopes e elipses, contribui para reforçar a expressão poética de uma existência fragmentária, interrompida, feita de fatos que se empilham aleatoriamente e se descartam displicentemente como objetos de despejo. Em construções estilísticas próximas às soluções estéticas adotadas no filme Cidade de Deus, parataxes, frases sincopadas, anacolutos e elipses mimetizam a voz 
gaguejante, engasgada e asfixiada daqueles que tampouco comem ou respiram, dos milhões de "João Gostoso" anônimos do continente latino-americano. $\mathrm{O}$ estilo poético de Carolina logra representar, metonímica ou metaforicamente, vidas fragmentadas e seres rompidos pela violência social, em sua peculiar e sofrida condição de existência.

Carolina de Jesus e seus filhos, oprimidos na senzala da fome, no gueto das favelas, irrompem na vida do leitor e acusam as formas de "ninguneo" que se praticam na sociedade brasileira: nessa obra, a expressão estética coincide com o conteúdo informativo do diário, uma obra "que expressa, em sua aparente frieza e objetividade, a subjetividade das vidas que por elas se mede", conforme sublinha Marisa Lajolo (2011, p. 443). Para tanto, Carolina serve-se de uma linguagem peculiar, paradoxal e antitética, em cujo âmbito articulam-se desvios ortográficos e gramaticais, expressões rebuscadas e anacrônicas, regionalismos e vocabulário culto, que por vezes se aproximam das criações poéticas do poeta Manoel de Barros: "As coisas jogadas fora // têm grande importância // - como um homem jogado fora." Em Carolina, o eu-lírico é também o objeto de seu próprio discurso, como se vê nesta passagem fragmentada à maneira de Barros: "E quando estou na favela // tenho a impressão que sou // um objeto // fora de uso, digno // de estar num quarto de despejo." Essa dupla função sujeitoobjeto espelha o posicionamento e o lugar discursivo a partir do qual fala a escritora, sua ambivalente visão de mundo, sua condição de autora à frente de seu tempo e de seu entorno, escravizada pela dura realidade da pobreza e da privação de educação formal.

A linguagem de Carolina corresponde à denúncia lançada por Eduardo Galeano, cujo texto relembra o estereótipo compartilhado pelos segmentos hegemônicos de que os "ninguneados" são pessoas "que no hablan idiomas, sino dialectos". Carolina serve-se de uma linguagem direta e multifacetada que se transforma em contundente grito de protesto, em denúncia contra as injustiças decorrentes da exclusão social, a começar pela impossibilidade de acesso à educação formal e ao letramento: “Não gosto de aludir os males físicos porque ninguém tem culpa de adquirir molestias contagiosas. Mas quando a gente percebe que não pode tolerar a impricancia do analfabeto, apela para as enfermidades" (Jesus, 2006, p. 24). Iletramento é a pior dentre as enfermidades sociais crônicas que inviabilizam uma existência minimamente humana, como se denuncia em Carolina, em texto cujos aspectos formais revelam e denunciam 
precisamente o aspecto contagioso do preconceito social contra aqueles que foram privados de educação formal.

Carolina, consciente de sua condição de favelada e ninguneada, subverte a história oficial ao despejar, das profundezas de seu quarto, as parcelas de realidade cotidiana que a historiografia grandiloquente teima em varrer para baixo do tapete. De forma complementar, ainda que na posição de um observador externo aos fenômenos observados, o escritor uruguaio sublinha que esses ninguneados "no figuran en la historia universal, sino en la crónica roja de la prensa local", assim como Carolina também registra, em uma das passagens de seu diário, o ponto de vista de um ninguneado que aspira a construir sua própria voz autoral:

Esqueci de citar que quando eu estava esquentando fogo as mulheres começaram a falar que haviam visto o retrato do Zuza no jornal. E estavam alegres. Percebi que o senhor Zuza com a festa que fez para o povo em vez de atrair amigos atraiu inimigos. Eis o que estava escrito no jornal do dia 26 de junho de 1958: 'Zuza, pai de santo, em cana'. 'Zuza' está em cana desde ontem, pois ele, que se chama na realidade José Onofre, e tem uma aparencia realmente imponente, mantinha para lucros extraordinários uma tenda de Umbanda no Bom Retiro, a Tenda do Pae Miguel Xangô (Jesus, 2006, p. 66).

No que tange à religiosidade, Galeano assume a voz de um observador externo, pretensamente suprassocial, e relembra que, no discurso das classes dominantes, esses ninguneados "no profesan religiones, sino supersticiones", sua fé tem o valor de mera crendice desprovida de valor transcendente. Ora, na voz autoral autorreferenciada de Carolina, a autora desdobra-se em personagem de si própria e afirma que sua fé traz resultados concretos, tem a força e a dimensão de qualquer outra forma de religião: "Eu estava indisposta, resolvi benzer-me. Abri a boca duas vezes, certifiquei-me que estava com mau olhado. A indisposição desapareceu sai e fui ao seu Manoel levar umas latas para vender" (Jesus, 2006, p. 9). Como se vê, Carolina estampa em letras impressas suas convicções e suas crenças, como forma de denúncia e recusa da opinião compartilhada pelo senso comum em relação a suas práticas religiosas.

Se, no discurso hegemônico, como relembra Galeano, os ninguneados "no hacen arte, sino artesanía, [...] no practican cultura, sino folklore", é preciso sublinhar o fato de que, mesmo com toda a repercussão internacional, a 
obra de Carolina Maria de Jesus permanece alijada do cânone literário, pois é preconceituosamente considerada uma forma de "artesanato literário", um pouco como se fosse um desses panos de prato pintados à mão e vendidos em feiras de economia solidária. Os trabalhos artísticos executados pelos "ninguneados" da nação, pelos filhos de "nadie" que "no tienen cara, sino brazos", são assimilados pelas classes dominantes a atos mecânicos de "braços" que seguem a força bruta e o instinto animal, escapam ao raciocínio e à abstração intelectual, são objetos utilitários privados de expressividade estética.

Eduardo Galeano assim denuncia o preço nulo que as classes dominantes atribuem aos ninguneados da nação, essas mesmas classes que, se retomamos o julgamento de Oscar Wilde, sabem o preço de todas as coisas, o valor de coisa alguma: "los nadies, que cuestan menos que la bala que los mata". Por seu lado, Carolina relembra que a condição dos excluídos é a de "projetos de gente humana" (Jesus, 2006, p. 20), seres inconclusos, imateriais, descartáveis. Assim, por meio de sua obra, Carolina contribui para a construção de uma identidade continental em que o cotidiano dos excluídos serve como fator de reflexão para a compreensão do sentido geral dos fatos e eventos por cujo intermédio constrói-se a América Latina.

\section{Reflexões finais e transitórias}

No âmbito do diálogo entre culturas, a literatura comparada apresentase como mediadora, haja vista o caráter relacional que se estabelece entre produções literárias de autores distintos, de povos distintos. Pelo viés comparatista, é possível entrever que os ninguneados de Octavio Paz e os nadies de Galeano congregam-se nas páginas de Quarto de despejo para, por meio da expressividade autoral da voz de Carolina de Jesus, trazer à luz e denunciar alguns entre os graves problemas crônicos dessa sociedade de identidade conflitante e corrediça: a América Latina. A leitura comparativa da imagem da exclusão social nessas páginas literárias induz a uma reflexão acerca das formas de representação das hierarquias sociais, um fenômeno mediador de sentido no conjunto da sociedade. Nas páginas analisadas, percebe-se que tanto a forma quanto o conteúdo dos textos revelam traços de pertencimento social: por um lado, temos engajados autores representantes de segmentos hegemônicos da sociedade, cujas linhas revelam um pensamento 
sistêmico que, de um ponto de vista externo aos processos de exclusão social, denunciam a precariedade das relações sociais na América Latina; por outro lado, contrapõe-se a voz autoral de uma mulher que lê os fatos ao mesmo tempo que é vítima das assimétricas relações de poder decorrentes do processo de formação da América Latina. Ao fornecer os instrumentos para a leitura contrastiva desses autores, a literatura comparada apresenta-se como o local privilegiado do encontro e da diferença e induz um "pensar de outro modo", como assinala o comparatista Daniel-Henri Pageaux (Pageaux, 2011, p. 260). Tal leitura permite descobrir que, nas linhas e entrelinhas de suas páginas, Carolina desdobra-se em personagem profundamente humano e, por meio do registro da micro-história, narra sua própria invenção da história coletiva, recorre a uma expressiva subjetividade autoral no plano da micro-história e da literatura, nega-se a aceitar passivamente a plurissecular condição de objeto invisível e descartável de uma sociedade utilitarista e reificante, e se propõe como sujeito construtor de sua própria existência. Por meio da materialidade significante que se manifesta nas palavras lançadas por Carolina sobre a página branca, o leitor pode aprofundar sua compreensão da história e da cultura do continente latino-americano e, por extensão, da própria humanidade.

\section{Referências}

CANDIDO, Antonio (1997). Formação da literatura brasileira. Belo Horizonte: Itatiaia.

CUNHA, Karla Pereira (2004). Busca por uma identidade latino-americana através da literatura: estudo das obras Cien Años de Soledad de Gabriel García Márquez e El Laberinto de la Soledad, de Octavio Paz. In: ENCONTRO MEMORIAL DO ICHS, 1. Anais..., Mariana: UFOP. Disponível em: <http://goo.gl/r0m0Mu>. Acesso em: 9 out. 2013.

EAGLETON, Terry (1997). Teoria da literatura: uma introdução. São Paulo: Martins Fontes.

FERRÉZ (2005a). Capão Pecado. São Paulo: Objetiva.

FERRÉZ (2005b). Literatura marginal. Talentos da escrita periférica. Rio de Janeiro: Agir. Disponível em: <http://goo.gl/X7DpLM>. Acesso em: 7 out. 2013.

GALEANO, Eduardo (1989). El libro de los abrazos. Montevideo: Siglo XXI.

GALEANO, Eduardo (1971). Las venas abiertas de América Latina. Madrid: Siglo XXI. 
JESUS, Carolina Maria de (2006 [1960]). Quarto de despejo: diário de uma favelada. São Paulo: Ática.

LAJOLO, Marisa (1998). A figura do negro em Monteiro Lobato. Presença pedagógica, Belo Horizonte, v. 4, n. 23, p. 21-31. Disponível em: <http://goo.gl/NS4Qki> Acesso em: 7 out. 2013.

LAJOLO, Marisa (2011). Carolina Maria de Jesus. In: DUARTE, Eduardo de Assis (Org.). Literatura e afrodescendência no Brasil: antologia crítica. Belo Horizonte: Editora UFMG. (v. 1, Precursores.)

LINS, Paulo (2002 [1997]). Cidade de Deus. São Paulo: Companhia das Letras.

MOREIRA, Maria Eunice (2003). Cânone e cânones: um plural singular. Porto Alegre: PUC-RS.

NAXARA, Márcia Regina (1998). Estrangeiro em sua própria terra. São Paulo: Annablume/FAPESP.

NINGUNEAR. In: Dicionario de la Real Academia Española. Versão online. Disponível em: <http:/ /goo.gl/H9Fsnb>. Acesso em: 12 jan. 2014.

PAGEAUX, Daniel-Henri (2011). Musas na encruzilhada: ensaios de literatura comparada. São Paulo: Hucitec; Santa Maria: UFSM; Frederico Westphalen: URI.

PAZ, Octavio (1983). Tiempo nublado. Barcelona: Seix Barral.

PAZ, Octavio (1990). Pequeña crónica de grandes días. Espanha: Fondo de Cultura Economica de España.

PAZ, Octavio (1991 [1969]). Posdata. 24. ed., México: Siglo Veintiuno.

PAZ, Octavio (1991 [1978]). El ogro filantrópico. Barcelona: Seix Barral.

PAZ, Octavio (1997 [1950]). El laberinto de la soledad. Madrid: Cátedra.

PAZ, Octavio (1998). La selva Lacandona. Vuelta, México, v. 20, n. 231, p. 8-12.

PORTO, Luana Teixeira (2012). Marginalidade e exclusão social: uma leitura do conto "Lixo e purpurina". Literatura em debate, Frederico Westphalen, v. 6, n. 10, p. 140-141.

RIBEIRO, João Ubaldo (1984). Viva o povo brasileiro. Rio de Janeiro: Nova Fronteira.

Recebido em abril de 2014.

Aprovado em setembro de 2014. 


\title{
resumo/abstract
}

\section{Carolina Maria de Jesus e a autorrepresentação literária da exclusão social na América Latina: olhares reversos aos de Eduardo Galeano e Octavio Paz}

\author{
Larissa Paula Tirloni \\ Marcelo Marinho
}

A literatura comparada dedica-se ao estudo das questões identitárias e das representações literárias interétnicas ou intersociais pelo viés privilegiado das relações interculturais. Em razão de seu amplo espectro de possibilidades de interpretação literária e cultural, a literatura comparada torna-se uma producente ferramenta para a análise dos diálogos transculturais em que se manifestam a aceitação ou a recusa das diferenças. Nessa perspectiva, o presente trabalho resulta de um estudo comparativo acerca da imagem literária da exclusão social, tendo como foco precípuo o relato autobiográfico da brasileira Carolina Maria de Jesus, em sua intersecção socialmente assimétrica com a escrita do mexicano Octavio Paz e do uruguaio Eduardo Galeano. No que se refere à subjetividade autoral, a brasileira lança mão de um poder expressivo que alcança significados para além da mera representação, pois seu testemunho parte de um lugar de enunciação que é aquele do próprio excluído: o conhecimento empírico da existência de uma catadora de papel, mulher, negra, migrante, mãe, descendente de escravos no Brasil, migrante sem perspectivas de vida, chefe solitária de família, moradora em favela, ser humano privado de cidadania. Nas páginas desse diário de desventuras, o testemunho existencial de Carolina traz à luz representações literárias e imagens simbólicas sobre uma importante parcela da sociedade que se encontra à margem, invisível aos demais segmentos da população. Essa parcela invisível da sociedade corresponde àqueles que Octavio Paz batiza como "ninguneados", àqueles que Eduardo Galeano homenageia com seu poema "Los nadies": seres humanos cuja existência é voluntariamente apagada ou ignorada nas manifestações culturais e nas relações sociais que conformam as hierarquias cotidianas e os modos de experiência de vida. Em próprio conhecimento de causa, Carolina corporifica uma voz autoral poeticamente expressiva que traz a lume a vida e a história silenciadas dos que se encontram à margem, por mais que sejam parte integrante da história de seu povo e do conjunto da humanidade.

Palavras-chave: exclusão social e literatura, Carolina Maria de Jesus, Eduardo Galeano, Octavio Paz. 


\title{
Carolina Maria de Jesus and the self-representation of social excluded groups in Latin America: a counter point of view on Eduardo Galeano and Octavio Paz poetic works
}

\author{
Larissa Paula Tirloni \\ Marcelo Marinho
}

The Comparative Literature is aimed at approaching cultural identity matters as well as interethnic or intersocial literary representations. Through its wide range of possible literary and cultural readings, the Comparative Literature becomes a useful tool to analyze transcultural dialogues as a locus of refusals or acceptations for human and social differences. Henceforth, this paper results of a comparative reading focused on Carolina Maria de Jesus autobiographical narrative and its implicit social exclusion literary images. In order to achieve that critical goal, this crisscrossed-reading takes into consideration the poetic and social ideas of Mexican diplomat Octavio Paz and Uruguayan journalist Eduardo Galeano. The selected text corpus brings forth literary representations and symbolic images of the society segment that lives in an extreme marginal position, making themselves invisible to other social groups. These out-of-sight people are called "ninguneados" by Octavio Paz, while Galeano pays a tribute to them in a denouncing poem that presents, from an external point of view, some aspects of their silenced life. Those people are the very human beings whose existence is voluntarily erased or ignored within every cultural manifestations or social relationships that configure hierarchical daily life as well as empirical ways of social living. From an internal point of view, Carolina de Jesus brings into light the silenced life and history of those people condemned to live as outsiders in modern social structures, despite their full belonging to their own people history as well as to the whole humankind history.

Keywords: social exclusion and literature, Carolina Maria de Jesus, Eduardo Galeano, Octavio Paz. 